\title{
PERAN PEMERINTAH DESA HARGOMULYO KECAMATAN KOKAP KABUPATEN KULON PROGO DALAM PENANGGULANGAN BENCANA KEKERINGAN
}

\author{
Rangga Riawan Haryo Praseno'), Gerry Katon Mahendra2) \\ 1)Administrasi Publik, Fakultas Ekonomi, Ilmu Sosial dan Humaniora, Universitas \\ 'Aisyiyah Yogyakarta \\ 2) Administrasi Publik, Fakultas Ekonomi, Ilmu Sosial dan Humaniora, Universitas \\ 'Aisyiyah Yogyakarta
}

\begin{abstract}
Abstrak
Indonesia memiliki iklim tropis, maka Indonesia hanya memiliki dua musim sepanjang tahun yaitu musim penghujan dan musim kemarau. Namun tetap saja kedua musim tersebut dapat berubah tergantung dari kondisi global yang tak menentu. Penelitian ini bertujuan untuk mengetahui peran Pemerintah Desa dalam menanggulangi Bencana Kekeringan di Desa Hargomulyo, Kecamatan Kokap, Kabupaten Kulon Progo. Hal ini juga untuk mengidentifikasi faktor pendukung dan penghambat dalam menanggulangi bencana kekeringan di Desa Hargomulyo, Kecamatan Kokap, Kabupaten Kulon Progo. Penelitian ini menggunakan pendekatan kualitatif deskriptif.Teknik pengumpulan data menggunakan wawancara mendalam, dan dokumentasi.Data yang telah diperoleh dinalisis melalui tahap reduksi data, teknik pengolahan, analisis data, penyajian data, dan penarikan kesimpulan. Hasil penelitian menunjukkan bahwa dengan adanyakeberhasilan dalam penanggulangan bencana kekeringan di Desa Hargomulyo ditunjukkan dengan tersedianya air bersih dari truk tanki pada bencana kekeringan di setiap tahunnya. Ada tiga peran yang mempengaruhi keberhasilan penanggulangan bencana kekeringan ini. Tiga peran tersebut adalah perencanaan, pelaksanaan, dan evaluasi. Dalam keberhasilan penanggulangan bencana kekeringan di Desa Hargomulyo terdapat faktor pendukung dan penghambat dalam setiap prosesnya. Pemerintah Desa diharapkan untuk membantu masyarakat dalam mengajukan proposal pengadaan toren ke Pemerintah Daerah apabila keterbatasan dana desa. Masyarakat dan pemerintah diharapkan dapat mencetuskan dan menjalankan program penanaman pohon sejak dini untuk pencegahan di masa yang akan datang.
\end{abstract}

Kata Kunci: Bencana Kekeringan; Penanggulangan; Peran; Pemerintah Desa.

\begin{abstract}
Indonesia has a tropical climate, so Indonesia only has two seasons throughout the year, namely the rainy season and the dry season. However, both seasons can change depending on uncertain global conditions. This study aims to determine the role of the Village Government in overcoming the Drought in Hargomulyo Village, Kokap District, Kulon Progo Regency. This is also to identify supporting and inhibiting factors in overcoming drought in Hargomulyo Village, Kokap District, Kulon Progo Regency. This study uses a descriptive qualitative approach. Data collection techniques use indepth interviews and documentation. The data that has been obtained are analyzed through the data reduction stage, processing techniques, data analysis, data presentation, and drawing conclusions. The results showed that the success in dealing with drought in Hargomulyo Village was shown by the availability of clean water from tank trucks in the event of drought every year. There are three roles that influence the success of this drought response. The three roles are planning, implementing, and evaluating. In the success of drought disaster relief in Hargomulyo Village, there are supporting and
\end{abstract}


inhibiting factors in each process. The Village Government is expected to assist the community in submitting Toren procurement proposals to the Regional Government if there are limited village funds. The community and government are expected to be able to initiate and run tree planting programs from an early age for prevention in the future.

Keywords: Drought Disaster; Countermeasures; Role; Village Government.

\section{PENDAHULUAN}

Keadaan geografis Indonesia yang demikian menjadikan Indonesia sebagai negara yang kaya akan Sumber Daya Alam namun juga rentan terhadap terjadinya bencana baik bencana alam, non alam maupun sosial. Jenis bencana dapat diklasifikasikan menjadi 3, yaitu bencana alam, bencana non alam dan bencana sosial. Bencana alam menjadi bencana yang paling banyak mengakibatkan kerugian baik materiil maupun non materiil. Bencana alam terbagi atas gempa, tsunami, longsor, banjir dan kekeringan. Bencana yang sering terjadi adalah kekeringan. Kekeringan merupakan bencana yang terjadi setiap tahunnya dikarenakan pergantian musim kemarau dan penghujan yang terjadi di Indonesia.

Adanya bencana kekeringan menjadikan sumber air mengering dan irigasi tidak dapat berjalan dengan lancar, lantas hal ini membuat berkurangnya persediaan air bersih menjadikan masyarakat mengalami kesusahan untuk memenuhi kebutuhan sehari-hari. Salah satu daerah yang sering terdampak kekeringan adalah Kabupaten Kulon Progo. 


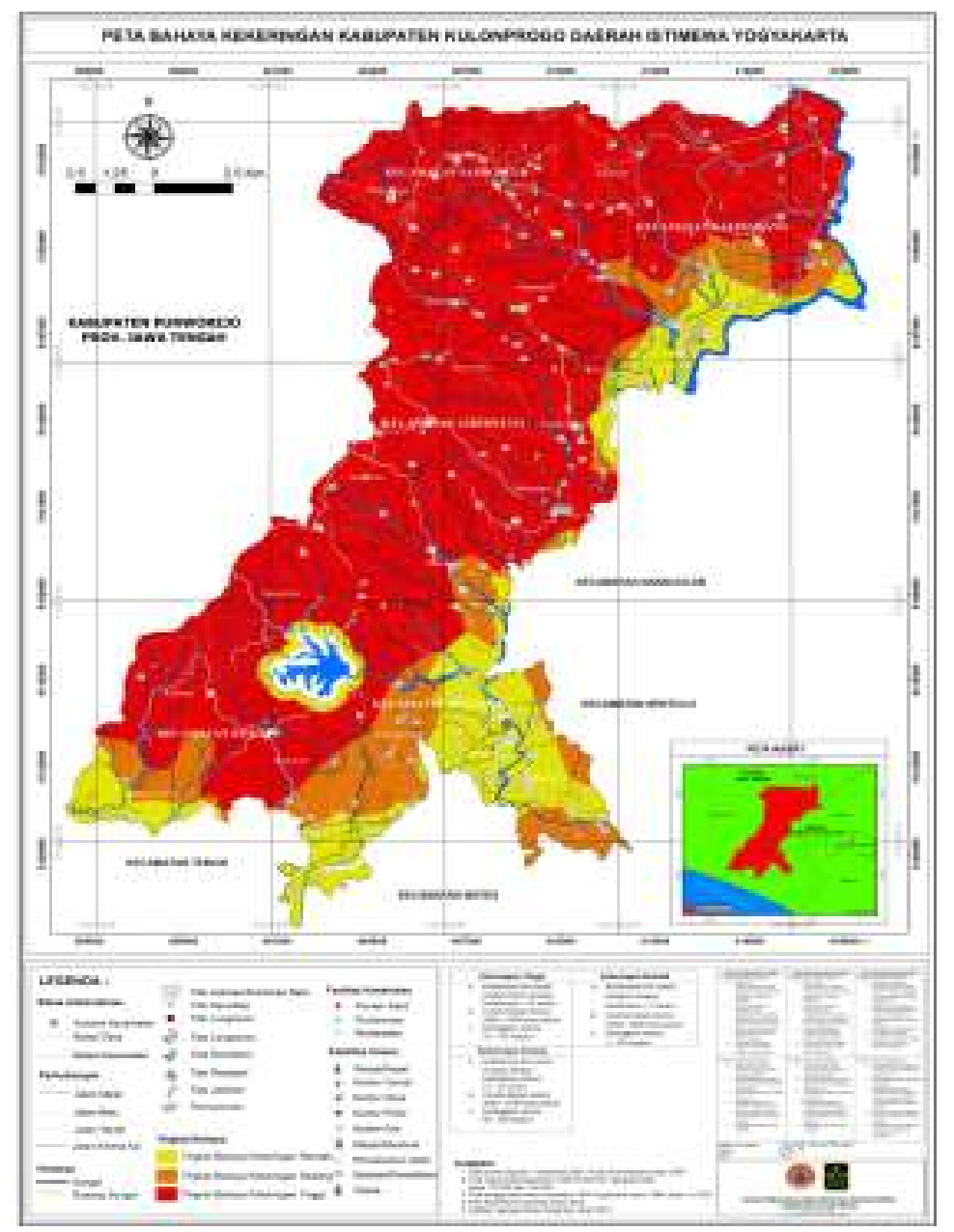

\section{Gambar 1. Jumlah Kekeringan yang terjadi di Kab. Kulon Progo}

Pada dasarnya Kabupaten Kulon Progo dapat dikatakan sebagai daerah yang rawan dengan bencana Kekeringan. Berdasarkan Badan Pusat Statistik kabupaten Kulon Progo tahun 2016 Kecamatan Kokap itu sendiri berada di dataran tinggi perbukitan menoreh dengan ketinggian 500-1000 meter diatas permukaan laut dan juga memiliki kemiringan tanah 8\% 15\%, salah satu desa yang terdampak kekeringan adalah Desa Hargomulyo.

Pemerintah menjadi pihak yang wajib berperan aktif dalam menanggulangi bencana kekeringan, hal ini dikarenakan pemerintah sebagai wakil rakyat bertanggungjawab dalam memastikan kesejahteraan, memberikan bantuan dan mengatasi permasalahan yang ada di masyarakat yang bersifat menyangkut kehidupan masyarakat luas. Berdasarkan hal tersebut, peneliti tertarik untuk melakukan penelitian terkait peran 
pemerintah desa dalam menanggulangi kekeringan di Desa Hargomulyo, Kec. Kokap, Kab. Kulon Progo.

Adapun penelitian terdahulu yang dijadikan bahan perbandingan serta menambah wawasan peneliti yaitu Penelitian dari Lailan Nahar (2016) yang berjudul Studi Deskriptif tentang Strategi Badan Penanggulangan Bencana Daerah Kabupaten Pasuruan dalam Penanggulangan Bencana Kekeringan Di Wilayah Kabupaten Pasuruan, Penelitian dari Dwi Hastuti (2017) yang berjudul Mitigasi, kesiapsiagaan, dan adaptasi masyarakat terhadap bahaya kekeringan, dan Penelitian dari Az. Abidin (2014) yang berjudul Peran Pemerintah Desa dan kesiapsiagaan Masyarakat dalam menghadapi bencana kekeringan.

Terdapat perbedaan mendasar pada ketiga penelitian terdahulu dengan penelitian yang akan datang yaitu terletak pada subjek dan lokasi penelitian.penelitian terdahulu menunjukkan adanya strategi mitigasi dan kesiapsiagaan yang dilakukan oleh pemerintah dalam menanggulangi kekeringandan penelitian yang akan dilakukan berfokus kepada Peran Pemerintah Desa dalam menghadapi bencana kekeringan di Desa Hargomulyo Kecamatan Kokap Kabupaten Kulon Progo, sehingga nantinya hasil penelitian ini dapat melengkapi dan menambah teori atau wawasan yang baru mengenai Peran Pemerintah Desa dalam menghadapi bencana kekeringan sekaligus menjadikan proses pembelajaran masyarakat pada umumnya.

\section{Peran Pemerintah Desa dalam Penanggulangan Bencana}

Istilah peran atau role merupakan sikap seseorang di dalam bermasyarakat atau lingkungan hidup seseorang. Seseorang tersebut merupakan actor yang harus memainkan beberapa peran seperti actor professional (Maurice Duverger, 2010). Menurut Undang-Undang No. 6 tahun 2016 Tentang Desa menjelaskan bahwa:

"Pemerintah Desa adalah Kepala Desa atau yang disebut dengan nama lain dibantu perangkat Desa sebagai unsur penyelenggara Pemerintahan Desa. Pemerintah desa sebagai penyelenggara 
pemerintahan dilaksanakan oleh kepala desa yang dibantu perangkat desa sebagai unsur penyelenggara pemerintahan desa."

Penelitian ini menggunakan teori peran yang terdiri atas perencanaan, pelaksanaan dan evaluasi dalam tindakan penanggulangan bencana. Untuk lebih detailnya tentang tahapan-tahapan peran pemerintah desa sebagai berikut :

\section{Perencanaan}

Menurut G.R Terry dalam Sukarna (2011) "Pemilihan dan penghubungan fakta-fakta serta pembuatan dan penggunaan perkiraan-perkiraan atau asumsi-asumsi untuk masa yang akan datang dengan jalan menggambarkan dan merumuskan kegiatan-kegiatan yang diperlukan untuk mencapai hasil yang diinginkan". Pemerintah desa melakukan beberapa langkah dalam perencanaan agar dapat merumuskan sebuah kebijakan, diantaranya :
a. Analisa situasi
b. Mengidentifikasi masalah dan prioritasnya.
c. Menentukan tujuan program.
d. Mengkaji hambatan dan kelemahan program.

2. Pelaksanaan

Pelaksanaan berfokus pada proses mencapai tujuan yang telah ditentukan dalam suatu kebijakan/program. Proses ini berusaha untuk mengubah pola operasional menjadi perubahan besar atau kecil sebagaimana keputusan yang telah ditetapkan sebelumya. Pelaksanaan pada dasarnya merupakan upaya untuk memahami apa yang seharusnya terjadi setelah kebijakan/program dilaksanakan (Mulyadi, 2015).

3. Evaluasi

Evaluasi merupakan proses untuk mengumpulkan, menganalisa dan menyajikan data serta infromasi penting mengenai objek evaluasi untuk dapat dinilai dan dibandingan dengan indikator dan hasil evaluasi untuk dapat diambil keputusan mengenai objek tersebut (Wirawan, 2011).

Menurut Undang-Undang No. 24 tahun 2007 tentang Penanggulangan Bencana dalam Pasal 1 ayat (6) menyebutkan bahwa: 
"Penyelenggaraan penanggulangan bencana adalah serangkaian upaya yang meliputi penetapan kebijakan pembangunan yang berisiko timbulnya bencana, kegiatan pencegahan bencana, tanggap darurat, dan rehabilitasi."

Selain itu Pedoman Umum Desa/Kelurahan Tangguh Bencana dalam Peraturan Kepala BNPB no 1 Tahun 2012. Pasal 4 undang-undang No. 24/2007 tentang Penanggulangan Bencana menyatakan bahwa penanggulangan bencana bertujuan untuk melindungi masyarakat dari ancaman bencana. Peraturan Kepala BNPB no 3 Tahun 2008 tentang Pedoman Pembentukan Badan Penanggulangan Bencana Daerah, menetapkan bahwa pemerintah daerah bertanggung jawab untuk melindungi masyarakat dari ancaman dan dampak bencana. Terkait dengan pemerintah desa meliputi kepala desa dan perangkat desa/pamong desa.

Berdasarkan teori di atas, dapat disimpulkan bahwa pemerintah desa memiliki peran yang penting dalam penanggulangan bencana kekeringan di wilayahnya. Peran pemerintah desa dalam penanggulangan bencana kekeringan dapat dibagi dalam tahap perencaan, tahap pelaksanaan dan tahap evaluasi.

\section{METODE PENELITIAN}

Jenis penelitian yang digunakan pada studi ini adalah jenis penelitian deskriptif dengan menggunakan pendekatan kualitatif. Penelitian deskriptif kualitatif merupakan rujukan metode penelitian yang ditujukan untuk mendeskripsikan serta menggambarkan fenomena yang terjadi baik secara alamiah maupun rekayasa manusia. Metode ini lebih berfokus pada karakteristik, kulitas dan keterkaitan antar kegiatan. Selain itu, metode ini tidak memberikan manipulasi atau pengubahan pada variabel-variable yang akan diteliti dengan kata lain metode ini menggambarkan dengan apa adanya.

Lokasi penelitian ini adalah Desa Hargomulyo yang memiliki kontur tanah berbukit bukit dan kandungan air tanahnya minim ditambah dengan 
banyaknya bebatuan yang menjadikan sebagian besar wilayah Desa Hargomulyo terdampak kekeringan disetiap tahunnya khususnya air bersih. Air bersih merupakan kebutuhan utama masyarakat untuk kehidupan sehari hari seperti untuk memasak, minum, mencuci dan juga untuk kebutuhan mandi disetiap harinya sekaligus untuk menjaga kesehatan masyarakat.

Untuk mendapatkan data penelitian, maka akan digunakan metode pengumpulan data sebagai berikut:

a. Wawancara

Mengumpulkan informasi dengan mengajukan sejumlah pertanyaan secara lisan untuk dijawab secara lisan pula terhadap 5 orang informan yang terdiri dari 4 kepala dusun dan 1 kepala desa.

b. Dokumentasi

Dokumentasi merupakan metode yang digunakan untuk melihat secata langsung data dan dokumen-dokumen yang berkaitan dengan objek penelitian. Dokumentasi digunakan sebagai penyempurna dari data wawancara (Ulfatin, 2013). Dokumen yang didapatkan dalam penelitian ini adalah Rencana Pembangunan Jangka Menengah Desa (RPJMDES), Database Desa Hargomulyo 2018 atau data jumlah konsumsi air minum penduduk desa beserta foto dan juga rekaman suara dari wawancara yang dilakukan (voice recorder).

\section{PEMBAHASAN}

Berdasarkan letak geografis, beberapa dusun yang ada di Desa Hargomulyo berada pada dataran tinggi sehingga mengakibatkan beberapa wilayah di Desa Hargomulyo mengalami bencana kekeringan setiap tahunnya. Dusun yang terdampak yaitu dusun Tangkisan 1, Tangkisan 2, Tangkisan 3 dan Kadigunung. Pada dasarnya hampir keseluruhan wilayah di Desa Hargomulyo mengalami bencana kekeringan, namun seiring berjalannya waktu tersisa 4 (empat) dusun yang mengalami kekeringan secara rutin hingga sekarang. 
Kekeringan yang terjadi berdampak pada sulitnya pemenuhan air bersih untuk kebutuhan sehari-hari seperti minum, memasak, mencuci dan lain sebagainya. Terlebih lagi, air merupakan kebutuhan mendasar bagi setiap manusia. Berdasarkan kondisi yang ada di Desa Hargomulyo, maka diperlukan adanya peranan pemerintah untuk menanggulangi bencana kekeringan yang terjadi secara rutin di Desa Hargomulyo. Hal tersebut tertuang dalam Undang-Undang Nomor 6 Tahun 2014 Tentang Desa dijelaskan bahwa Pemerintahan Desa adalah penyelenggaraan urusan pemerintahan dan kepentingan masyarakat setempat dalam sistem pemerintahan Negara Kesatuan Republik Indonesia.

1. Peran Pemerintah Desa dalam Perencanaan

Desa Hargomulyo mengalami bencana kekeringan setiap tahunnya dikarenakan letak geografis yang berada di dataran tinggi dan beberapa faktor lainnya. Berdasarkan hasil wawancara, ditemukan bahwa Desa Hargomulyo setiap tahunnya mengalami kekeringan di empat (4) dusun dan disebabkan oleh letak geografis yang berada di dataran tinggi serta adanya penebangan pohon yang dianggap sebagai penampung air secara alami oleh masyarakat.

Dengan adanya permasalahan tersebut, maka pemerintah desa harus mengambil langkah untuk mengatasi bencana kekeringan yang melanda masyarakat dengan sebuah program atau kebijakan. Sebuah program atau kebijakan tentu memerlukan perencanaan yang baik agar pelaksanaan juga dapat berjalan dengan baik. Sama halnya dengan pemerintah Desa Hargomulyo yang melakukan perencanaan dalam menanggulangi kekeringan di Desa Hargomulyo. Pada hasil wawancara dengan sekretaris Desa Hargomulyo menunjukkan bahwa perencanaan dilakukan dengan terstruktur yaitu tidak melupakan masyarakat dalam proses perencanaan. Selain itu, adapun anggaran yang disediakan oleh pemerintah desa setiap tahunnya untuk menanggulangi bencana kekeringan yang memang setiap tahunnya terjadi di Desa Hargomulyo.

Berdasarkan hasil wawancara dengan masyarakat, pemerintah desa melibatkan masyarakat pada proses perencanaan penanggulangan 
bencana kekeringan dengan mendengarkan keluhan dan apa yang masyarakat butuhkan untuk dapat dicarikan alternative pemecahan masalahnya. Peneliti menganalisa bahwa pemerintah desa berperan baik dalam proses perencanaan menanggulangi bencana kekeringan di Desa Hargomulyo dengan melibatkan masyarakat secara langsung selaku terdampak dan penerima manfaat program.

2. Peran Pemerintah dalam Pelaksanaan

Setelah melalui tahap perencanaan, maka akan masuk pada proses pelaksanaan atau implementasi program. Pelaksanaan mengacu pada tindakan untuk mencapai tujuan yang telah ditetapkan dalam suatu keputusan.proses ini merupakan tindakan untuk mengubah keputusan yang telah diambil menjadi pola operasional.

Berdasarkan hasil musyawarah terdapat 4 (empat) dusun yang paling terdampak kekeringan. Melihat hal tersebut, pemerintah desa mengambil tindakan dengan bekerja sama dengan Dinas Sosial untuk program PAMSIMAS (Program Nasional Penyediaan Air Minum dan Sanitasi Berbasis Masyarakat) dan adanya bantuan air bersih dari pihak Corporate Social Responsibility serta pihak swasta lainnya berupa penampungan air. Program PAMSIMAS dicetuskan oleh Dinas Sosial, namun untuk mendapatkan bantuan diperlukan adanya inisiatif dari pemerintah desa untuk mengajukan proposal terlebih dahulu.

Adapun informasi yang didapatkan dari informan lainnya mengungkapkan hal yang sama bahwa pemerintah desa bekerja sama dengan PAMSIMAS serta adanya bantuan air bersih dari pihak swasta. Berikut tabel distribusi air Desa Hargomulyo:

Tabel 1. Data Jumlah Sumber Air Minum Desa Hargomulyo RPJM Desa Tahun 2015-2020

\begin{tabular}{|l|l|l|l|l|l|l|l|}
\hline Desa & PDAM & Sumur & $\begin{array}{l}\text { Sumur } \\
\text { Bor }\end{array}$ & $\begin{array}{l}\text { Mata } \\
\text { Air }\end{array}$ & $\begin{array}{l}\text { Air } \\
\text { Isi } \\
\text { Ulang }\end{array}$ & $\begin{array}{l}\text { Lain- } \\
\text { lain }\end{array}$ & Satuan \\
\hline Hargomulyo & 167 & 1902 & 7 & 349 & 368 & 0 & $\begin{array}{l}\text { Rumah } \\
\text { Tangga }\end{array}$ \\
\hline
\end{tabular}

Atas pernyataan informan, maka peneliti menarik kesimpulan bahwa peran pemerintah desa sudah sangat baik dalam melaksanakan 
program untuk memenuhi kebutuhan masyarakat dibantu dengan peran penting masyarakat selaku penerima manfaat dan adanya bantuan dari pemerintah daerah serta pihak swasta dalam menjalankan program penanggulangan bencana kekeringan di Desa Girimulyo.

\section{Peran Pemerintah Desa dalam Evaluasi}

Pelaksanaan program yang baik harus diiringi dengan proses evaluasi untuk mengetahui apakah program sudah dijalankan dengan baik atau belum. Evaluasi merupakan proses yang tersusun secara sistematis dan bertujuan untuk menyajikan informasi serta menganilisis program yang memiliki tolak ukur. Hasil dari evaluasi dapat menentukan kelanjutan arah program atau untuk membuat kebijakan yang baru.

Pemerintah Desa Hargomulyo melakukan proses evaluasi di penghujung tahun dengan melibatkan masyarakat dalam musyawarah kembali yang dihadiri oleh kepala dusun dan RT setempat. Dari hasil wawancara dapat disimpulkan bahwa pemerintah desa melakukan evaluasi setiap tahunnya dengan kembali melibatkan masyarakat selaku terdampak kekeringan dan penerima manfaat program. Evaluasi dilakukan untuk mengetahui sejauh mana perkembangan program dan dampaknya seperti apa untuk masyarakat. Berdasarkan evaluasi yang dilakukan setiap tahun, pemerintah desa dapat menarik kesimpulan terkait kerugian saat kekeringan dan dampak yang diperoleh masyarakat setelah adanya program sehingga dapat melakukan tindakan sesuai dengan kebutuhan masyarakat.

Berdasarkan hasil temuan lapangan, peneliti menganalisa bahwa pemerintah desa Hargomulyo sangat baik peranannya dalam evaluasi pelaksanaan program penanggulangan bencana kekeringan di Desa Hargomulyo.

Menanggulangi bencana kekeringan bukan hal yang mudah bagi pemerintah dan masyarakat. Banyak faktor pendukung dan faktor penghambat jalannya penanggulangan. Berikut faktor pendukung dan faktor penghambat berdasarkan hasil wawancara: 
Faktor Pendukung, hasil temuan lapangan mengungkapkan bahwa sikap sigap pemerintah desa dan gotong royong masyarakat menjadikan penanggulangan bencanan kekeringan di Desa Hargomulyo, Kecamatan Kokap, Kabupaten Kulon Progo dapat berjalan dengan baik.

Faktor Penghambat, hasil temuan lapangan membuat peneliti dapat menganalisa bahwa akses untuk ke wilayah masyarakat sulit karena berada di dataran tinggi sehingga sulit dijangkau oleh truk pengangkut air untuk dapat dropping air bersih ke penampungan masyarakat. Oleh karena itu, truk hanya dopping air di bagian luar saja berdasarkan masing-masing dusun. Karena hal tersebut, mengharuskan warga mengambil air menggunakan motor ke penampungan dengan membawa jerigen.

\section{KESIMPULAN}

Peneliti menarik kesimpulan bahwa Desa Hargomulyo mengalami kekeringan secara rutin setiap tahunnya dikarenakan letak geografis wilayah yang berada di dataran tinggi dan jenis tanahnya yang berbedabeda setiap dusun. Oleh karena itu, dari 11 (sebelas) dusun, hanya ada 4 (empat) dusun yang mengalami bencana kekeringan secara rutin dan terparah pada tahun 2018 yaitu berlangsung selama kurang lebih 10 bulan. Dalam menanggulangi bencana kekeringan, diperlukan adanya peran yang baik dari pemerintah desa serta dibantu oleh masyarakat dan pihak ketiga.

Peneliti menyimpulkan bahwa pemerintah desa Hargomulyo, Kecamatan Kokap, Kabupaten Kulon Progo memiliki peran yang sangat baik dalam menanggulangi bencana kekeringan di Desa Hargomulyo khususnya di 4 (empat) dusun yang terdampak secara langsung kekeringan. Adapun simpulan yang dapat ditarik dari peran pemerintah Desa Hargomulyo dalam menanggulangi kekeringan, yaitu:

1. Peran pemerintah desa dalam perencanaan

Hasil penelitian menunjukan peran pemerintah desa dalam perencanaan sangat baik karena melibatkan masyarakat dalam merencanakan 
program dan kebijakan apa yang akan digunakan untuk menanggulangi kekeringan.

2. Peran pemerintah dalam pelaksanaan

Peran pemerintah dalam pelaksanaan juga sangat baik karena mendata masyarakat terlebih dahulu dan mengajukan proposal ke pemerintah daerah untuk mendapatkan bantuan air bersih. Selain itu, pemerintah desa juga menyediakan dana darurat setiap tahunnya untuk bencana kekeringan di Desa Hargomulyo.

3. Peran pemerintah pada tahap evaluasi

Peran pemerintah pada tahap evaluasi juga sangat baik dikarenakan kembali melibatkan masyarakat selaku penerima manfaat dan diadakan setiap tahun.

Adapun faktor yang mempengaruhi penanggulangan bencana kekeringan yaitu didukung dengan kekompakan masyarakat dan sikap sigap pemerintah desa dalam menanggulangi bencana dengan adanya bantuan air bersih dan kerjasama antar warga membuat tampungantampungan seadanya untuk mempermudah proses distribusi air bersih. Selain itu, truk pengangkut air bersih sulit untuk menjangkau beberapa wilayah di Desa Hargomulyo karena lokasi berada didataran tinggi.

\section{DAFTAR PUSTAKA}

Abidin, Ahmat Zainal. 2014. Peran Pemerintah Desa dan kesiapsiagaan Masyarakat dalam menghadapi bencana kekeringan. Artikel Publikasi Ilmiah Surakarta, Universitas Muhammadiyah Surakarta.

Badan Penanggulangan Bencana Nasional. 2007. Penanggulangan Bencana. Undang-Undang Nomor 24 Tahun 2007.

Badan Penanggulangan Bencana Nasional. 2015. Pedoman Pembentukan BPBD. Peraturan Kepala BNPB Nomor 3 Tahun 2008.

Duverger, Maurice. 2010. Sosiologi Politik, Raja Grapindo Persada, Jakarta. 
Hastuti, Dwi. 2017. Mitigasi, kesiapsiagaan, dan adaptasi masyarakat terhadap bahaya kekeringan. Tesis. Universitas Sebelas Maret, Surakarta.

Mulyadi, D. 2015. Perilaku Organisasi dan Kepemimpinan Pelayanan. Bandung: Alfbeta.

Nahar, Lailan. 2016. Studi Deskriptif tentang Strategi Badan Penanggulangan Bencana Daerah Kabupaten Pasuruan dalam Penanggulangan Bencana Kekeringan Di Wilayah Kabupaten Pasuruan, Jurnal Kebijakan dan Manajemen Publik. 4 (2).

Sukarna. 2011. Dasar-Dasar Manajemen. Bandung: Mandar Maju.

Ulfatin, Nurul. 2013. Metode Penelitian Kualitatif di Bidang Pendidikan. Teori danAplikasinya, Bayumedia Publishing, Malang.

Wirawan. 2011. Evaluasi: Teori, Model, Standar, Aplikasi dan Profesi. Jakarta: Rajagrafindo Persada. 